\title{
Poor Quality ECG
}

National Cancer Institute

\section{Source}

National Cancer Institute. Poor Quality ECG. NCI Thesaurus. Code C114172.

An electrocardiographic recording that does not show proper quality for reasons that are not otherwise described. (CDISC) 